\title{
情報交換を伴う仮想迷路探索行動実験 \\ WAY-FINDING BEHAVIOR WITH VERBAL COMMUNICATION IN A VIRTUAL MAZE
}

鈴木 利 友*, 岡 崎 甚 幸**

Toshitomo SUZUKI and Shigeyuki OKAZAKI

\begin{abstract}
We developed the multi-user system for the experiments of way-finding with verbal communication in a virtual maze. We experimented competitive-cooperative way-finding with the multi-user system: two subjects make a pair and two pairs compete with each other in finding a goal. We also experimented cooperative way-finding: four subjects cooperate in finding a goal. According to these experiments, we have found seven kinds of way-finding behaviors, state-transition from one behavior to another, kinds of communication words, and characteristics of image map drawn by subjects.
\end{abstract}

Keywords: way-finding behavior, communication, virtual space, maze, competition, cooperation

探索行動、情報交換、仮想現実空間、迷路、競合、協調

序

これまで巨大迷路探索歩行実験りや、迷路や地下鉄駅舎でのアイ カメラを用いた探索歩行実験 ${ }^{23)}$ を行ってきた。その結果の分析か ら、歩行者が棵境からどのように情報を獲得し、その情報を探索歩 行にいかに利用するかを明らかにしてきた。しかし探索歩行中の步 行者は、罾境からの情報だけでなく、空間を共有する他の歩行者と 情報交換を行い、そこから得た情報も歩行に利用する。この探素歩

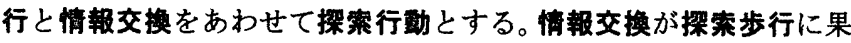
たす役割の解明は、避難行動など群集歩行の観点からみた建築空間 の評価や設計のために重要である。

他者からの情報が偨索歩行に与える影響を調べた実験的研究には、 地図や目的地一の方向教示、同行教示が空間把握や経路探索に与え る影響を調べた研究 ${ }^{4) 、}$ 線画による仮想迷路空間を用いて避難行動 におけるリーダーシップ効果を調べた研究 ${ }^{5)}$ 、地下街や室内を使っ て誘遵者と避難者の人数比を変化させて、避難誘導法の有効性の比 較を行った研究 ${ }^{6}$ などがある。また、歩行者がどのような場面で道 を尋就るのかを携帯電話やP H S を用いて調べた研究》もある。し かしこれらの実験での情報の提供は、実験者から被験者に対し一方 的に行われている。複数の被験者による情㫰交换を伴う探索行動実 験を試みた研究には、地図を使ったペアによる経路探索がその後の
同一経路の地図なしでの単独步行および地図描画に与えた影響を調 べた研究がある ${ }^{8)}$ 。しかし歩行経路や、共同で探索するか分担して 探索するかなどといった探索方法の制限を加えずに探索した実証的 研究はまだ例がない。それは現実空間で複数の步行者による探索行 趿实験を行い、会話や歩行軌跡の詳細なデータをとり、分析するの が困難なためである。なお単独での探索歩行時の発話を分析した研 究には日色らによるものがある9

本研究ではマルチユーザ型仮想現实空間を構築し、複数の步行者 が自由に情却交換可能な仮想迷路探索行動实験を行った。その結果 の分析を通して、情報交換や探索歩行と環境との関倸の解明を目指 す。本システムによる実験は視野が狭い、キーボードを用いて頭部 運動や身体運動を行うなど現実空間での実験と異なる点がある。し かし4人の被験者からなる集団で、探索方法や探索経路、会話の制 限を加えることなく、会話や歩行軌跡のデータを詳細に記録し、分 析することが可能である。

探索行動中の情報交換は、歩行者の相互依存関係によって大きく 変化する。そのうちもっとも典型的なものが協調型と競合型の関保 である。協拥型の関係とは「複数の個人または集団が 1 つの目標に 向かって力を合わせることによってはじめて目標が達成できる事態」 である。本研究では歩行者間に協調型の関係を形成するため、複数
* 京都大学大学院工学研究科 博士後期課程 - 工修

** 京都大学大学院工学研焭科 教授・工博
Graduate Student, Graduate School of Engineering, Kyoto Univ, M. Eng. Prof., Graduate School of Engineering, Kyoto Univ., Dr. Eng. 
の歩行者が同一の目的地を協力して挆索する状況を設定し、実験を 行った。競合型の関係とは「複数の個人または集団が 1 つの目標を 達成しようとして競い合い、1人または 1 集団がその目標を達成す ると、他はそれに妨害されて目標を達成できなくなる事態」である。 すべての歩行者が競合型の関係にある状況では情報交換が生じにく い。そこで、協調型の関係によって形成された集団の 2 組が競い 合って目的地を探索する状況を設定し、どのような情郝交換が行わ れるかを調べた。情報交換の詳細な構造分析は今後の課題とする。 構造分析をすすめることによって、情報交換を伴う探索行動のモデ ル化やそれによるシミュレーションが可能になると考えている。

瀷境として採用した迷路は実際の建築空間に比べ壁の形が複雑で あるが、渨境を構成する要素の種類は少なく、探索行動への影響が わかりやすい。本研究では迷路内の分岐点をすべて十字路と $\mathrm{T}$ 字路 で構成した。これによって步行者の経路選択に影響する環境の要素 を単純化し、選択可能な経路を限定するとともに、言語化が容易な 実験空間にして、情報交換と探索歩行の関係を分析しやすくした。

\section{1. 実験システムの構筑および実験方法}

\section{1-1. Freellalk-VRML による実験システムの楎築}

仮想現実空間内で複数の被験者が同時に挆索歩行と情報交換が可 能なFreeWalk-VRML を開発した。3次元空間内を移動しながらネッ トワークによる音声や表情が交換可能なシステムである FreeWalk ${ }^{10)}$ に、VRML97による建築・都市空間の表示、壁との衝突判定、床や階 段面の高さ判定、および自分自身の仮想現実空間内の化身であるア バタ Avatar の身体表現や頭部回転運動(水平および垂直)を遒入 したものである。システムは Browser と Server からなる。

Browser は、VRML97 で記述した仮想現実空間に参加するための インターフェイスである。各被験者には Browser が起動した計算 機を 1 台ずつ割り当てる。被験者はアバタを介して仮想現実空間に 参加する。Browser には自分のアバタの目から見た仮想現実空間の 風景が表示される(写真1)。画面に表示される視野角は垂直方向 90 。、水平方向 $106^{\circ}$ である。またキーボード操作で頭部を水平から
上下にそれぞれ $60^{\circ}$ 、進行方向から左右にそれぞれ $60^{\circ}$ ずつ回転す ることができる。したがって頭部の回転によって上下 $210^{\circ}$ 、左右 $226^{\circ}$ の広がりを見ることができる。各被験者はキーボードで自分 のアバタの位㯰や向きなどを操作することにより、仮想現実空間を 歩行する。

各被験者の計算機にマイクとヘッドホンのついたヘッドセットを 備え付けた(写真 2)。被験者はヘッドセットを装着して他の被験者 と会話する。仮想現実空間内でのアバタ間の距離に応じて音量を減 衰させたため、遠くのアバタと会話ができない。また被験者の表情 を撮影するC C Dカメラを各被験者の計算機のモニタに装着した。 アバタの頭部は正面を底面とした四角錐で、C C D カメラで撮影し た被験者の顔のビデオ画像を、リアルタイムで対応するアバタの頭 部前面に表示する。これにより、相手の表情をそのアバタの頭部に 見ることができる(写真 1$)$ 。

Server は仮想現実空間に参加している各アバタの位睓や向きな どを管理し、自動的に記録する機能をもつ。Browser と Server は LAN によって相互に接続している。各被験者のアバタの位直、向き、 音声、表情は Server を介してリアルタイムで共有される。

\section{1-2. 实験方法}

同一被験者群 (4人)に対し、2人が組になり他の組と競争して迷路 内の目的地を探索する䪭合協調型の探索行動実験と、4人の被験者 が協調して目的地を探索する協調型の探索行動実験を続けて行う。

\section{1-2-1. 新合協調型の探索行動実験}

実験装置 計算機 5 台を配置する(図 1)。被験者がネットワークを 介して音声や表情を交換できるよう、座席は実験室内に分散して配 置する。実験者用の計算機はServer で、仮想現実空間を鳥瞰図で 表示、そこに各アバタの現在位置をリアルタイムで表示する。被験 者に割り当てた4台は Browser で、それぞれにC C Dカメラとヘッ ドセットを用意する。実験中の各アバタの位置や身体・頭部の向き は Server が自動的に記録する。会話は、当初は全員の音声を Server に集め、8mmビデオカメラやテープレコーダで録音した。し かし結果をより詳細に記録するため、各被験者ごとにビデオデッキ

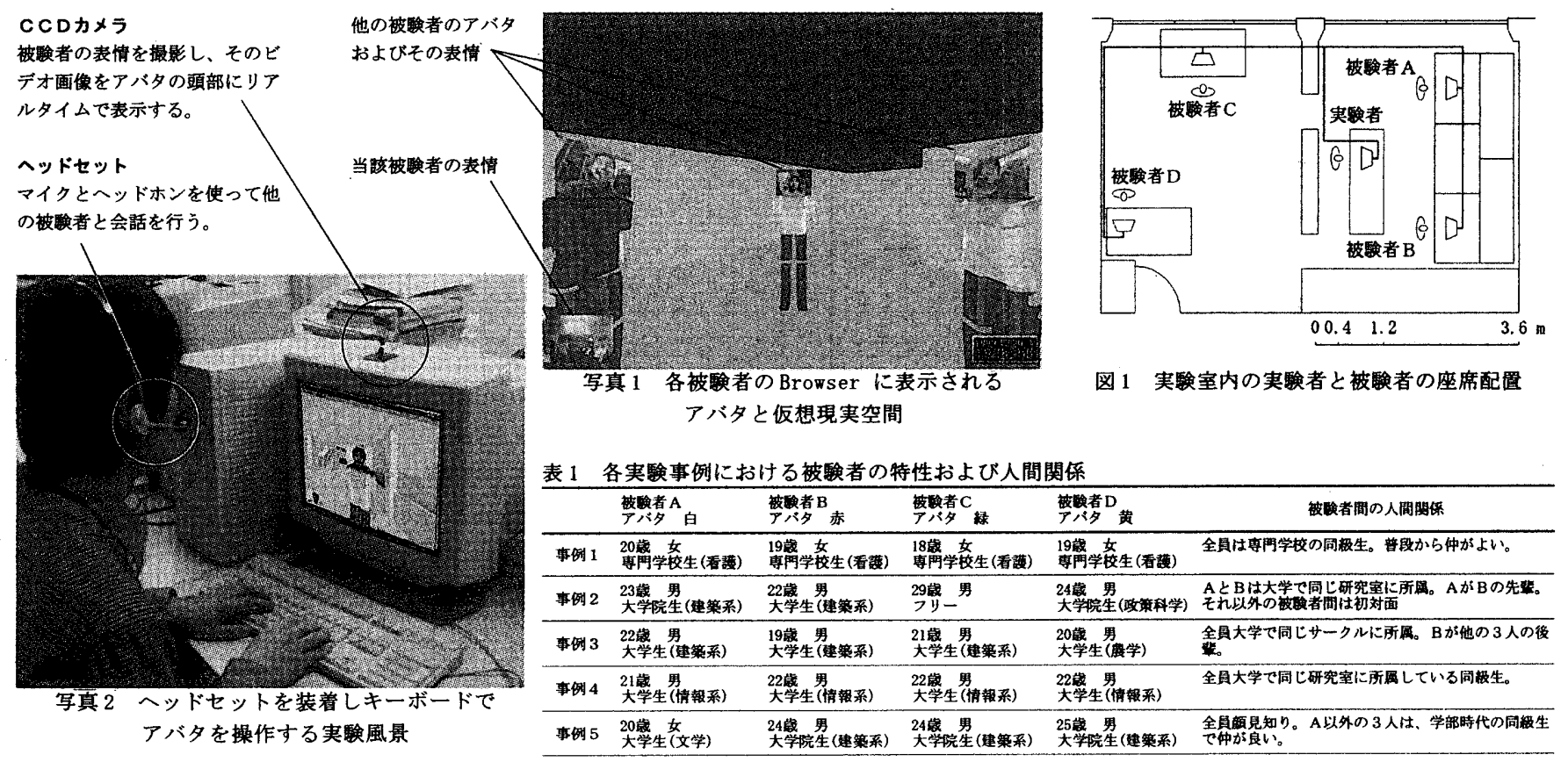


を 1 台ずつ用意し、計算機のモニタから出力した Browser の画像 と、計算機の音声出力の双方を合わせて、各被験者ごとに 1 本のビ デオテープに録画・録音する方法に変更した。

被験者 4 名の被験者を 1 組にして実験 5 事例を行う。計 20 名の被 験者は 10 代から 20 代の大学生、大学院生、専門学校生、社会人で、 学生の専攻はさまざまである。また各事例での被験者間の人間関係 も、友達、研究室の先䨽後輩や同級生、初対面など多様である(表1)。 罩境 (仮想現実空間) 実験に使用した迷路の平面図を図 2 に示す。 被験者の経路選択に影響する環境の要素を絞るため、迷路の全分岐 点をT字路と十字路で構成する。また被験者が会話で表現可能な環 境の情報を増やすため、交差点や突き当たりや袋小路の壁(図 2 中 1 〜 15, AB, CD)に、サイン(食物や動物などのイラスト)を貼る（8〜 15 は同じサインを 2 枚向かい合わせに配置)。Gゴールには「ゴー ル」と記したサインを貼る。4人の被験者をペアに分ける。被験者 $\mathrm{A}$ と $\mathrm{B}$ のアバタは図 2 中 $\mathrm{AB}$ 、被験者 $\mathrm{C}$ と Dのアバタは図 2 中 $\mathrm{CD}$ の地 点に互いに向かい合わせの状態で立ち、同時に探索行動を開始する。 別々の場所からスタートした互いに競合関係にあるアバタ同士が、 実験中に出会うことを意図して設計した迷路である。

教示 実験開始直前に次のように教示する。「なさんは今、同じ迷 路に 2 組のチームに分かれて立っています。白の○○さんと赤の $\triangle$

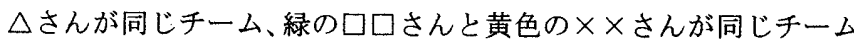
です。こちらが合図をしたら、他のチームよりも早く、ゴールと書 かれたサインの場所に同じチームの 2 人で到着してください。いっ しょに探す、別れて探すなど、探し方は自由です。互いに見えてい る人同士なら、同じチームの人だけでなく、別のチームの人とも話 をして構いませんが、見えていない人どうしでは話をしないように してください。終了の合図はこちらからします。」実際には全員が ゴールに到着するまで終了の合図は行わない。

アンケート 実験終了後各被験者に、イメージマップおよび風景の 描画をさせる。質問内容は以下の通りである。「今みさんが歩いた 迷路の平面図を、あなたが覚えている範囲で描いてみてください。 また、あなたの印象に残った迷路の風景があったら、それも描いて みてください。」アンケートを行うことは、被験者には実験終了時ま で知らせていない。

\section{1-2-2. 協調型の探索行動実験}

実験装置・被験者 1-2-1 と同じ。

環境（仮想現実空間）実験に使用した迷路の平面図を図 3 に示す。 1-2-1の迷路と同様に全分岐点はT字路と十字路で構成し、交差点 や突き当たりや袋小路(図 3 中 $1 \sim 21 ， \mathrm{~S}$ ) の壁にサインを貼る（14 〜21は同じサインを2枚向かい合わせで配置)。Gはゴールで「ゴー ル」と記したサインを貼る。4人の被験者のアバタはサイン $\mathrm{S}$ 前 に互いに向かい合わせの状態で立ち、同時に探索行動を開始する。 教示 実験開始直前に次のように教示する。「みなさんは、迷路の 中に立っています。白が○○さん、赤が $\triangle \triangle$ さん、緑が口ロさん、 黄色がメメさんです。こちらが合図をしたらみんなで協力してゴー ルと書かれたサインを探し、全員で集合してください。いっしょに 探す、別れて探すなど、探し方は自由です。制限時間は 5 分としま す。互いに見えている人同土とは話をして構いませんが、見えてい ない人どうしでは話をしないようにしてください。終了の合図はこ ちらからします。また、先ほどの実験の後にはアンケートをとりま
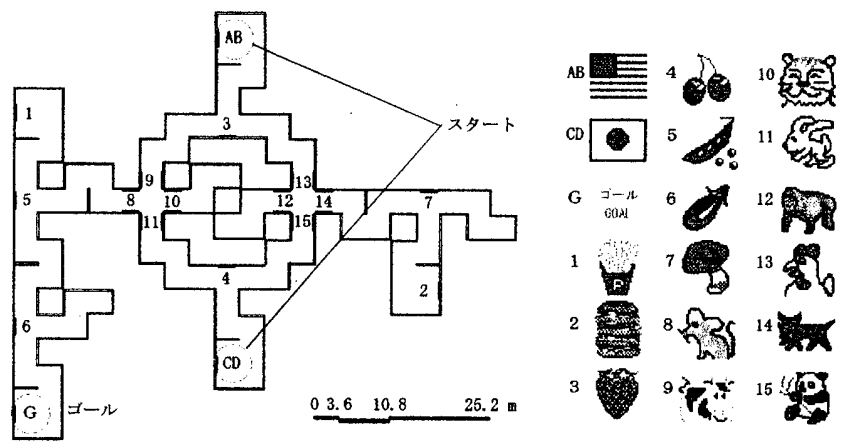

図 2 競合協調型の探索歩行実験で使用した迷路の平面図およびサイン
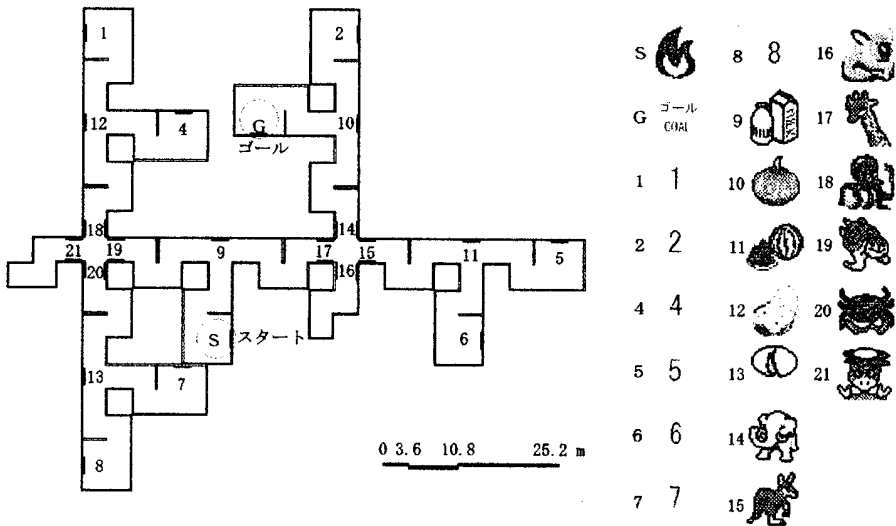

図 3 拹調型の探索歩行実験で使用した迷路の平面図およびサイン

したが、本実験の後にはアンケートはとりません。」

本実験後にアンケートをとらないことを教示したのは、本実験で もイメージマップや風景描画を書かされると予想した被験者が、空 間を記憶することに気をとられ、それが実験結果に大きく影響する 可能性があるからである。また実験開始後 5 分を経過しても実験は 続行する。

\section{2. 実験結果の分析}

\section{2-1. 実験中にみられる行動}

実験中の行動を歩行行動や会話の違いに着目して分類する(表2)。 探索する行動と、探索しない追従、誘導、待機の諸行動がみられる。

探索する行動は目的地探索行動と歩行者探索行動に分かれる。目 的地挅索行動には、単独で探索する目的地単独搡索行動と、他の步 行者と同行しながら探索する目的地共同探索行動がある。目的地単 独探索行動中は比較的発言が少ない。目的地共同探索行動中は「右 行きます」「とりあえずまっすぐ」「どっち行けばいいんかなあ」な ど環境や方向に関寸る発言、歩行者探索行動中は「○○ちやんがお らん」「みんなどこにいる?」「ちょっと待ってや」など、歩行者の 場所や行動に関する発言が多いのが特徽である。

追従行動は他者の背中を追いながら歩行する。誘道行動は誘遒方

表 2 步行行動や会話の違いに着目した探索行動の分類

\begin{tabular}{|c|c|c|c|}
\hline \multicolumn{3}{|c|}{ 行動の分類 } & 意味 \\
\hline \multirow{3}{*}{$\begin{array}{c}\text { 探索する } \\
\text { 行動 }\end{array}$} & \multirow{2}{*}{ 目的地探索行動 } & 目的地単独探索行動 & 単独で目的地を探索 \\
\hline & & 目的地共同探索行動 & 他者と同行しながら目的地を探索 \\
\hline & \multicolumn{2}{|l|}{ 步行者探续行動 } & 步行者を探索 \\
\hline \multirow{4}{*}{$\begin{array}{c}\text { 探索しない } \\
\text { 行動 }\end{array}$} & \multicolumn{2}{|l|}{ 追徤行動 } & 地者に追従して歩行 \\
\hline & \multirow{2}{*}{ 溙導行動 } & 吸着誘導行動 & 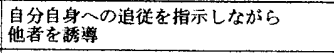 \\
\hline & & 指示唀洋行動 & 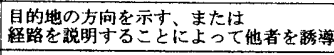 \\
\hline & \multicolumn{2}{|l|}{ 待機行動 } & ある䭪所にとどまる行動 \\
\hline
\end{tabular}


法の違いから吸着誘道行動と指示誘道行動に分かれる。吸着誘遵行 動は、自分自身への追従を指示することによる誘導で、誘遒者の発 言には「ついてきて」「こっち」などがある。吸着誘導を受けた被誘 導者は通常追従行動をとる。指示誘導行動は、目的地への方向を示 す、または経路を説明することによる誘導で、誘導者の発言には「こ の奥」「○○の方に曲がって下さい」「○○のところを左に曲がった らゴールです」などがある。他者一の追從の指示も指示誘導である。 指示誘導を受けた被誘導者は、通常目的地探索行動をとる。

待機行動は、状況の変化を待つ、または状況を把握するために、 ある場所にとどまる行動である。必ずしも静止していなくてよいが、 例えば目的地探索行動などにおいて交差点で一時的に立ち止まり、
周囲を見渡す行動などは含まない。

両実験中の全歩行者が以上 7 種類のいずれの行動をとっていたか、 目的地発見前と後に分け時系列で調べる(図 4)。その結果、被験者 や集団によってみられる行動に差が大きいが、目的地発見前は目的 地探索、追従行動、発見後は歩行者探索、待機、誘導行動を多くと る傾向がある。競合協調型の探索行動実験では、ペア 2 人が同行す る傾向が強く、目的地共同探索行動が多い。協調型の探索行動実験 では、4人が分担して探索する傾向が強く、目的地単独探索、待機、 誘導の諸行動が多い。

既往研究で取り上げられている行動には以下のものがある。巨大 迷路探索步行実験 1)では、接近行動、迁回行動、右回り、左回りな
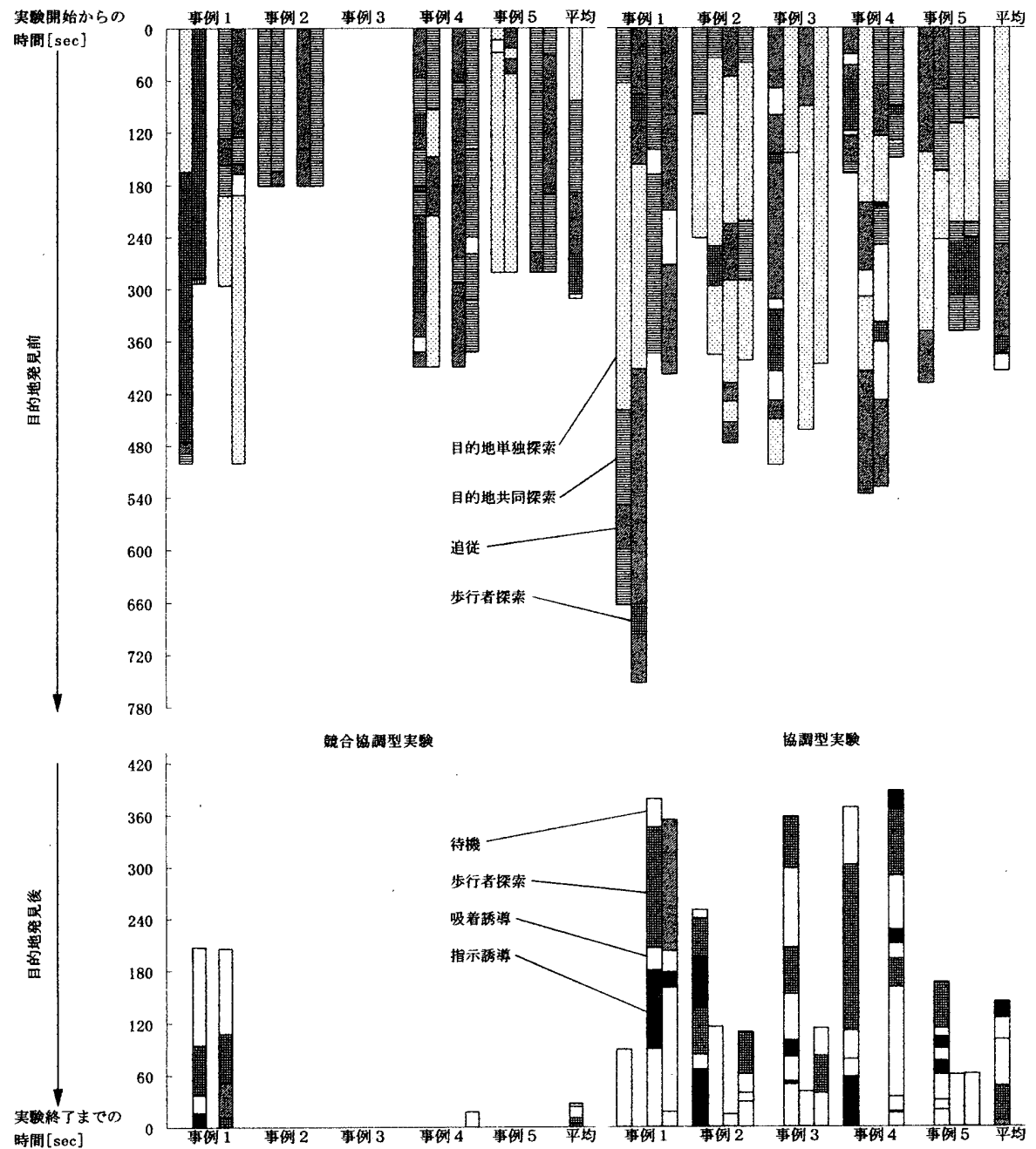

図4両探索行動実験における各事例でのそれぞれの被験者の行動

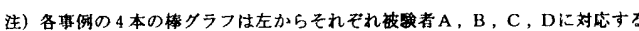

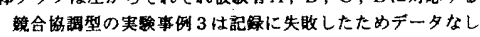

表 3 協調型の探索行動実験でみられた状態遷移の要因（入力）

\begin{tabular}{|c|c|c|c|c|}
\hline \multicolumn{3}{|c|}{ 大分類 } & 小分類 & 意味 \\
\hline \multirow{2}{*}{\multicolumn{3}{|c|}{ 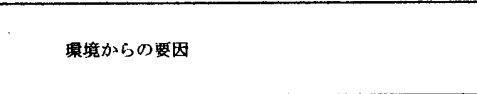 }} & 目的地桑見 & 目的地を発見する \\
\hline & & & 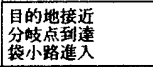 & 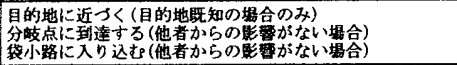 \\
\hline \multirow{6}{*}{$\begin{array}{l}\text { 他の步行者 } \\
\text { からの要因 }\end{array}$} & \multirow{4}{*}{$\begin{array}{c}\text { 情却交換に } \\
\text { よる要因 }\end{array}$} & 1)指示を年えられる & \multirow{4}{*}{ 表4类照 } & 情報交换の送り手が受け手の行動を指示する \\
\hline & & 2)情報を与えられる & & 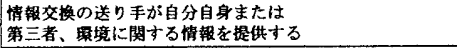 \\
\hline & & 3)指示を求められる & & 情般交㡎の送り手が自分自身の行動について指示を求める \\
\hline & & 4)情報を求められる & & 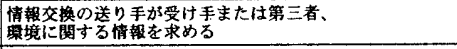 \\
\hline & \multirow[t]{2}{*}{$\begin{array}{l}\text { 情城交撸に } \\
\text { よらない要因 }\end{array}$} & 他の歩行者との位膡関俰 & 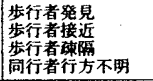 & 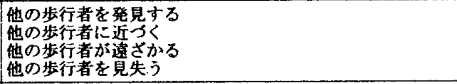 \\
\hline & & 他の步行者の変化 & 同行者目的地発見 & 同行している歩行者が目的地を発見する \\
\hline \multicolumn{3}{|c|}{ 内的要因 } & 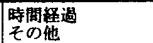 & 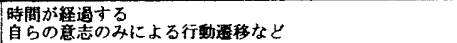 \\
\hline
\end{tabular}
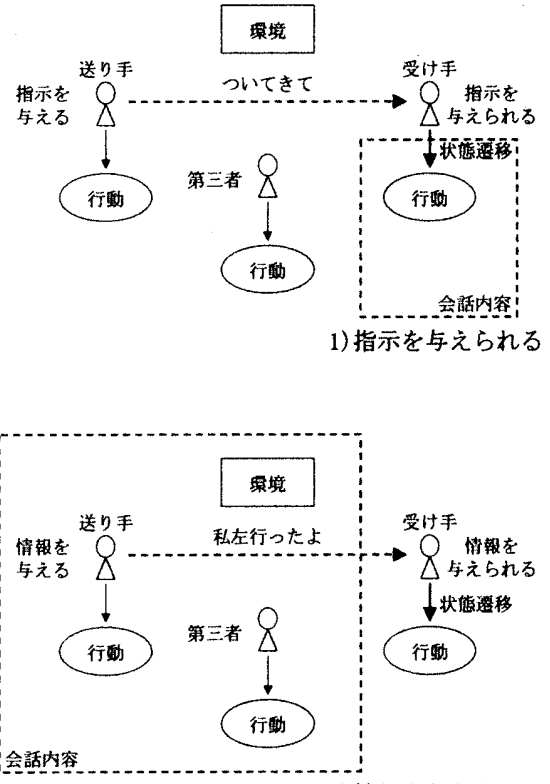

2）情報を与えられる

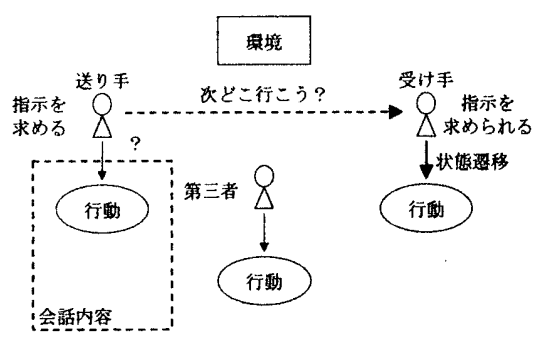

3)指示を求められる

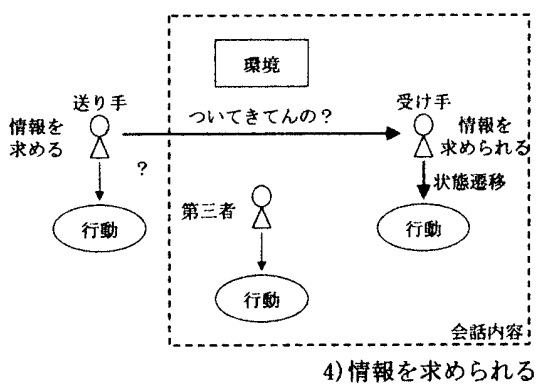

図 5 状態遷移の要因(入力) となる情報交換の種類 
どの行動を見出し、それをもとにシミュレーションモデルを構築し た。舟橋 ${ }^{4)}$ は探索行動として迷い、探索、確認、追従を、室崎 ${ }^{11}$ (は 避難経路選択の特性として、㷌巣性、日常動線志向性、向光性、向 開放性、易視経路選択性、至近距離選択性、直進性、本能的危険回 避性、理性的安全志向性、付和雷同性を挙げている。また釘原 ${ }^{5)}$ 避難時の集合行動の特徴として、脱出反忘の活発化、追従、固着、 攻撃、利已的行動の増加、譜歩行動の低下を明らかにした。杉万6) は避難誘導法に吸着誘導法、指差誘導法の 2 種類があるとし、誘導 者と避難者の人数を変化させ、両者の有効性を比較している。以上 の中で、帰巣性、日常動線志向性、向光性、向開放性、至近距離選 択性、本能的危険回避性、理性的安全志向性、付和雷同性、脱出反 応の活発化、固着、攻慗、僙歩行動は、今回の実験で明らかにでき ない。それは本実験が緊急を要する避難行動でないこと、火や煙の ない仮想迷路での探索歩行実験であることに起因すると思われる。

\section{2-2. 状態僄移の要因となる情報交換の分類}

歩行者がある行動をしている状態から別の行動をしている状態に遷 移することを状態遷移とする。状態僄移の要因(入力)は、環境、他の 歩行者、それ以外 (内的要因)のものからに分かれる(表3)。他の歩行者 からの要因にはさらに情報交換によるものとよらないものがある。こ の情報交換の要因を、それが送り手や受け手の行動に対してもつ意味 の違いから以下の 4 種類に分類する(図 5)。

1）指示を与えられる 送り手が受け手の行動を指示する。「ついてき て」などの発言がこれに当てはまる。指示を与えられた受け手が送り 手の指示に従い、状態遷移をする場合がある。

2)情報を与えられる 送り手が自分自身または第三者、環境に関する 情報を提供する。「私左行ったよ」「行き止まり」などがこれに当ては まる。情報を与えられた受け手が、その情報をもとに何らかの判断を 下し、状態遷移をする場合がある。

3)指示を求められる 送り手が自分自身の行動について指示を求める。 「次どこ行こう?」などの発言がこれに当てはまる。指示を求められた 受け手がその発言に対して何らかの反応を示し、状態遷移をする場合 がある。

4)情報を求められる 送り手が受け手または第三者、環境に関する情 報を求める。「ついてきてんの?」などの発言が当てはまる。情報を求 められた受け手がその発言に对して何らかの反応を示し、状態遷移を する場合がある。

Bales ${ }^{12)}$ によると、集団の成員が目的達成のために行う情報交換に

表 5 協調型の探索行動実験全事例における行動と会話(出力) との関係

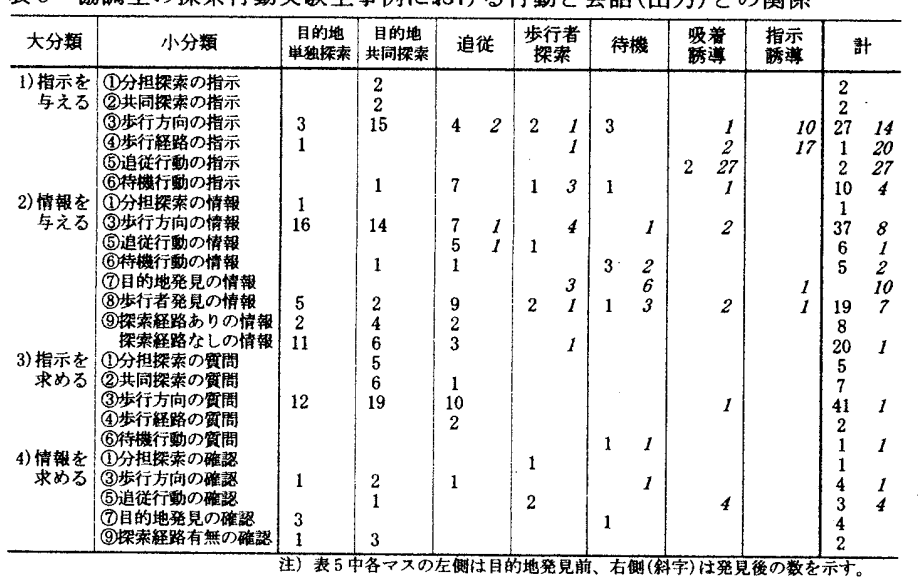

表 4 協調型の探索行動実験でみられた情報交換の会話内容による分類

\begin{tabular}{|c|c|c|}
\hline 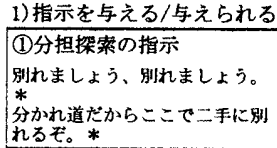 & \multirow{4}{*}{ 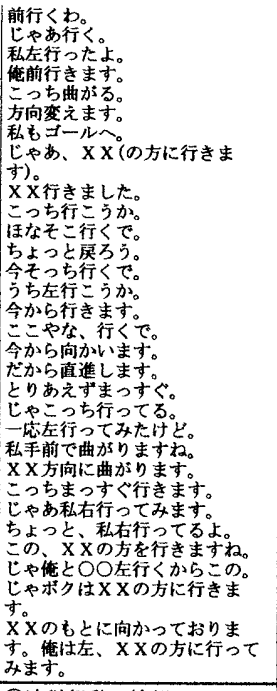 } & \multirow{2}{*}{ 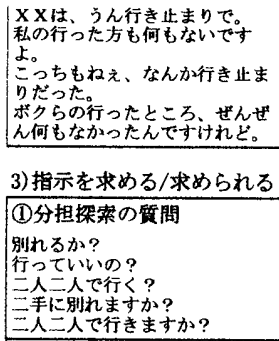 } \\
\hline 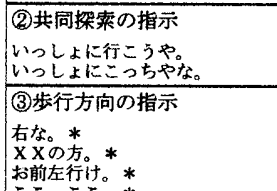 & & \\
\hline 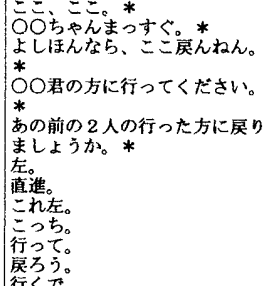 & & 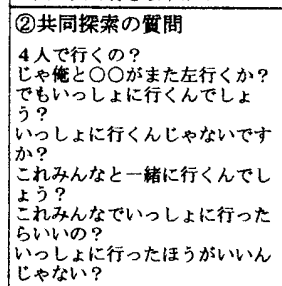 \\
\hline 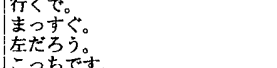 & & 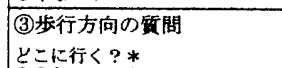 \\
\hline 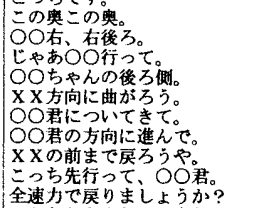 & 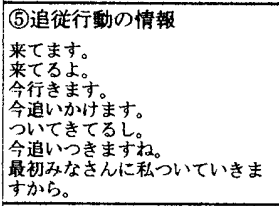 & 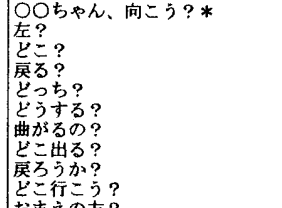 \\
\hline 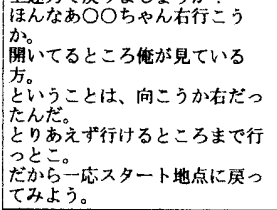 & 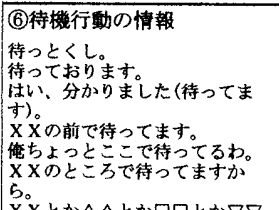 & 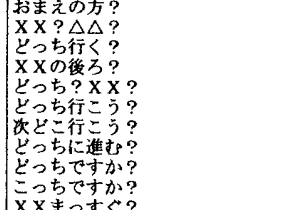 \\
\hline $\begin{array}{l}\text { (4)歩行程路の指示 } \\
\text { xのの方に曲がっでさい＊ }\end{array}$ & 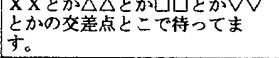 & \\
\hline 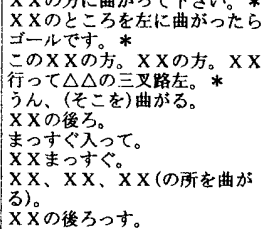 & 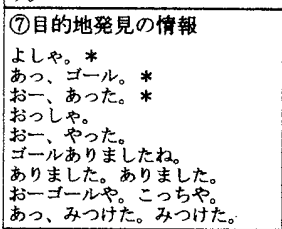 & 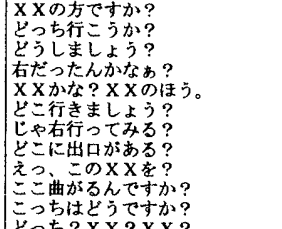 \\
\hline 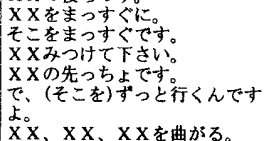 & 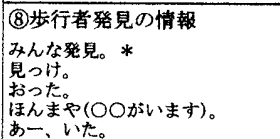 & 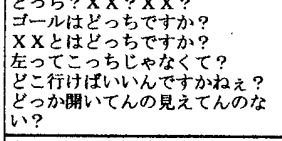 \\
\hline 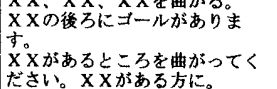 & 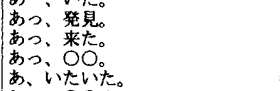 & $\begin{array}{l}\text { (4)渉行経路の質問 } \\
\text { どこに? } \\
\mathrm{x} \times \text { ○ととこです? }\end{array}$ \\
\hline 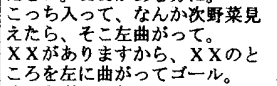 & 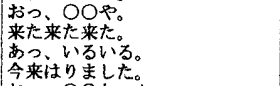 & 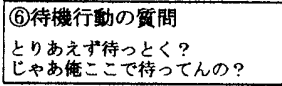 \\
\hline 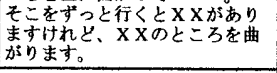 & 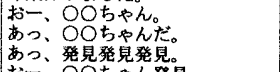 & 4)情報を求める/求められる \\
\hline (5)追従行動の指示 & 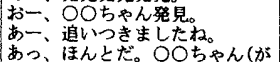 & $\begin{array}{l}\text { (1)分担探索の確被 } \\
\text { 别れたん? }\end{array}$ \\
\hline そきで。 & 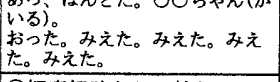 & 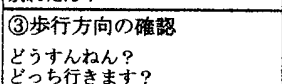 \\
\hline 淹のちについてきたら。 & 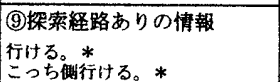 & 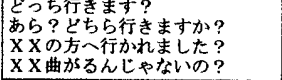 \\
\hline $\begin{array}{l}\text { 等っといて。* } \\
\text { 咅っといてな。 } \\
\text { ちょっとここの交差点立 } \\
\text { て。 }\end{array}$ & 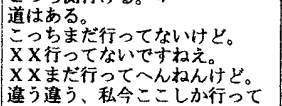 & $\begin{array}{l}\text { (5)追従行動の確翟 } \\
\text { ついてきてんの?* } \\
\text { なんだ、真後ろついてきてた } \\
\text { ん?* }\end{array}$ \\
\hline 2)情報を与える/与えられる & き止まりじゃないね & ついてきてる? \\
\hline (1)分担探索の情報 & 分か几道や。 & (7)目的地発見の確諰 \\
\hline $\begin{array}{l}\text { うん、○○ちゃんと(別れた)。 } \\
\text { (3)步行方向の情郬 } \\
\text { 右行きます。* }\end{array}$ & $\begin{array}{l}\text { (9)探索経路なしの情報 } \\
\text { 行き止まり。* } \\
\text { だめですね。こっちないです } \\
\text { わ。* }\end{array}$ & $\begin{array}{l}\text { あった? } \\
\text { みつかった? } \\
\text { なんかあった? } \\
\text { ヨールありました? }\end{array}$ \\
\hline 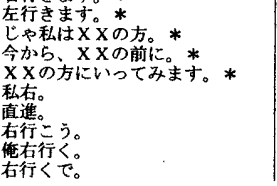 & 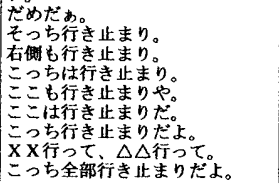 & 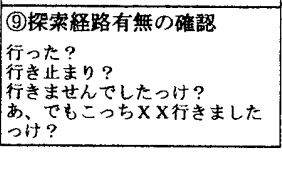 \\
\hline
\end{tabular}

注) $O O$ は人名、 $\mathrm{xx} 、 \Delta \Delta 、 \square 0 、 \nabla \nabla$ は互以に異なるサインの名前

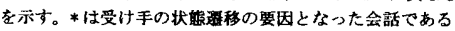


は社会的情動的な領域 social-emotional area と課題の領域 task area に分かれる。本実験で social-emotional area に当てはまる発 言には「おー、ファイトです」などがあるが、状態遷移の要因にはな らなかったため、ここでは取り扱わない。さらに task area には「示
唆、方向」「意見、評洒、分析」「オリエンテーション、情報」の意味 をあて、これらを与える場合を attempted answers、求める場合を questions としている。「示唆、方向」は本論でいう指示、「オリェン テーション、情報」は情報にあたる。「意見、評価、分析」は本実酫で 表 6 坫調型の探索行動実験全事例における状態臹移とその要因(入力)との関俰

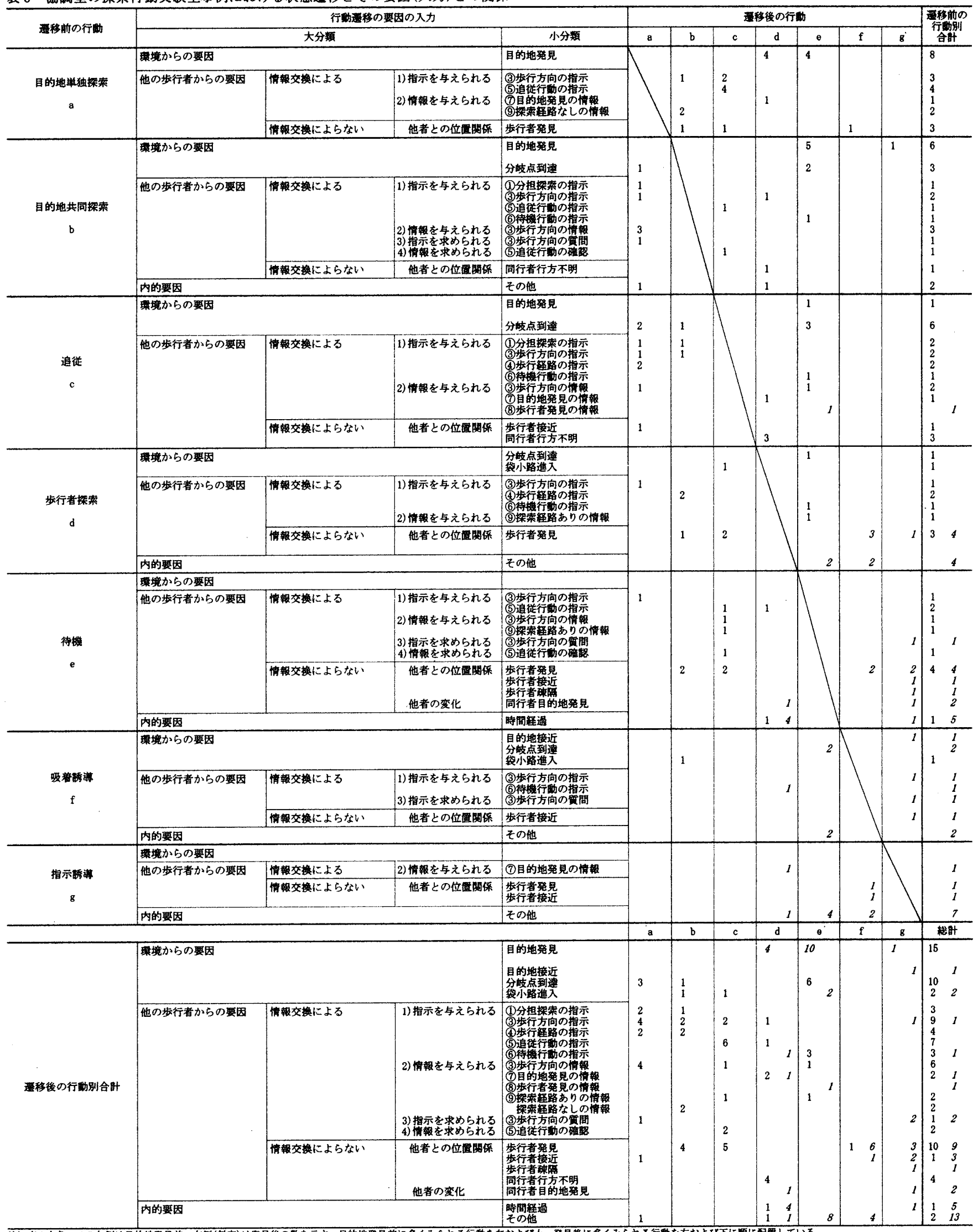


は少なく、しかも指示または情報と明確に区別できなかった。それは Bales が研究対象にした討論などと違い、本実験中の被験者は意見を 長時間述べあったり、評価や分析を詳細に行なったりせず、比較的短 時間に自身の行動を決定する傾向が強いことに起因する。

状態僄移の要因となった 1)〜4)の情報交換について、その指示や情 報の内容をさらに分析し、送り手または受け手の行動に関係する内容 と、周囲の状況に関係する内容に分類できた。「○○君は向こう行って る」のような、第三者の行動に関係する情報交換による状態遷移はな かった。行動に関係する内容は(1)分担して探索すること(2)共同で探索 すること(3)歩行する方向(4)歩行する経路(5)追従行動(6)待機行動、行動 以外に関係する内容は(7)目的地の発見(8)歩行者の発見(9)挆索する経路 の有無に分類できる。協調型の探索行動実験中にみられた(1) (9)の 内容をもつ会話を表 4 に示した。

\section{2-3. 協調型の探索行動実験における行動と会鲐 (出力)との関係}

歩行者が各行動時に、表 4 に挙げた会話を行った回数を、目的地 発見前後に分けて表 5 に示す。図4の行動別時閒割合との比較から、 目的地発見前は目的地共同探索行動、発見後は誘導行動中の歩行者 が、最も積極的に情報交換を行うことがわかる。目的地発見前の步 行者は歩行方向の指示や情報、質問、探索経路なしの情報など、経 路探索に直接関係する情報交換が多い。また追従行動時には歩行者 発見に関する多くの情報を与える。一方目的地発見後は誘導行動中 に、歩行方向、歩行経路、追従行動に関する多くの指示を与える。 情報や指示を他者に求めることは少ない。

\section{2-4. 協調型の探索行動实馀中の状態遭移とその要因となる入力の関係}

表 $3 、$ 表 4 の分類に基づいて、歩行者の状態遷移とその要因 (入力) との関係を調べた(表6)。目的地発見前は環境や情報交換による要 因、発見後は歩行者の位置関係や内的要因による状態遷移が多いこ とがわかる。

\section{2-5. 被験者やその集団の特性と行動との関係}

図 4 に示すように、本実験では各被験者、事例ごとの行動に特徵 的な違いがある。そこで事例ごとの実験の概要を述べる。
事例 1 競合協調型実験 AB組：独力で探索しようとするAと、 積極的に相手に追従したがるBのペアである。Aが単独行動をとっ たため、BもAを見失い単独行動になった。CD租：マイペースだ が他者にも気を使うCと、相手に追従したがるDのペアである。し かしCは競合実験にもかかわらずゆっくり探索しようとしたため、 Dは時間経過とともに別行動をとりだした。BとCは互いに競合し ながら目的地を発見した。そして铉制しあいながらしばらく待機行 動をとった後、ペアを組む相手を探索に向かった。Bが Aを発見し、 目的地へ誘導し、勝利した。協調型实験 Cは前実験のはじめと同 様、Dに対してリーダーシップを発揮した。誰かに追従したがった DはCに経路選択の判断を任せた。独力で探索しようとする $\mathrm{A}$ と、 $\mathrm{A}$ に追従しようとしたが見失った Bは、単独行動をとることが多 かった。CとDは目的地を先に発見したのち、Cがリーダーシップ をとってA、Bを探索し、誘導した。

事例 2 競合協調型实験 $\mathrm{AB}$ B 組 : 研究室の先輩の A は、後輩の $\mathrm{B}$ を引きつれて探索しリーダーシップを発揮した。BはAの指示に従 いながら、自らも周囲の状況を把握し助言した。CD組 : 積極的に 他者に追従したがるCは、Dに追従することをはじめに宣言した。 Dは初対面のCを常に気にしながら共同で探索した。協調型实験 Cは前実験同様、他者に追従することをはじめに宣言した。しかし Aはみんなで分かれて探索するよう提案した。後笫のB $\mathrm{B}$ 初対面の Dはそれに従い、分担して探索した。C，は前実驗同様Dに追従しつ つ、しばしば単独行動もとったが、その経路選択は混乱した。一番

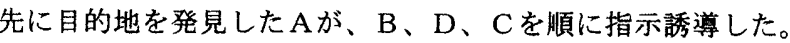

事例 3 協調型実駼 4 人とも単独行動をとった。全く会話しない Dは、他者を無視して独力で探索した。やはり会話に消極的な $\mathrm{B}$ と Cも黙々と探索した。誰かに追従したがっていたAも、誰にも相手 にされないので単独行動をとった。B、D、Cの順に目的地を発見 するが、いずれの者も他の歩行者を積極的に誘導しようとはしな かった。

事侧 4 競合協調型実験 AB組: 積極的に相手に追従したがるA

表 7 両実験の各事例における被験者およびその集団の特性

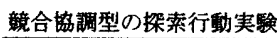

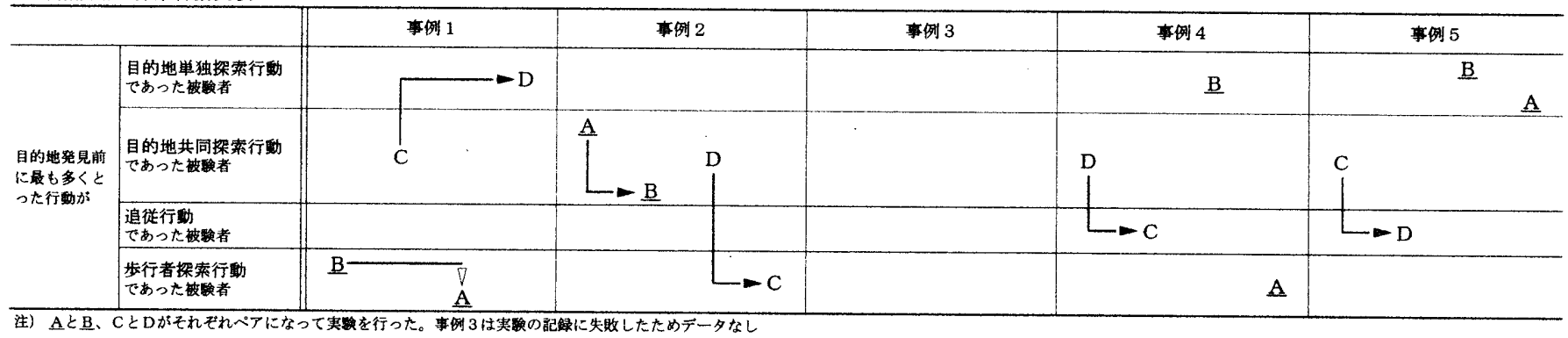

坫調型の探索行動実験

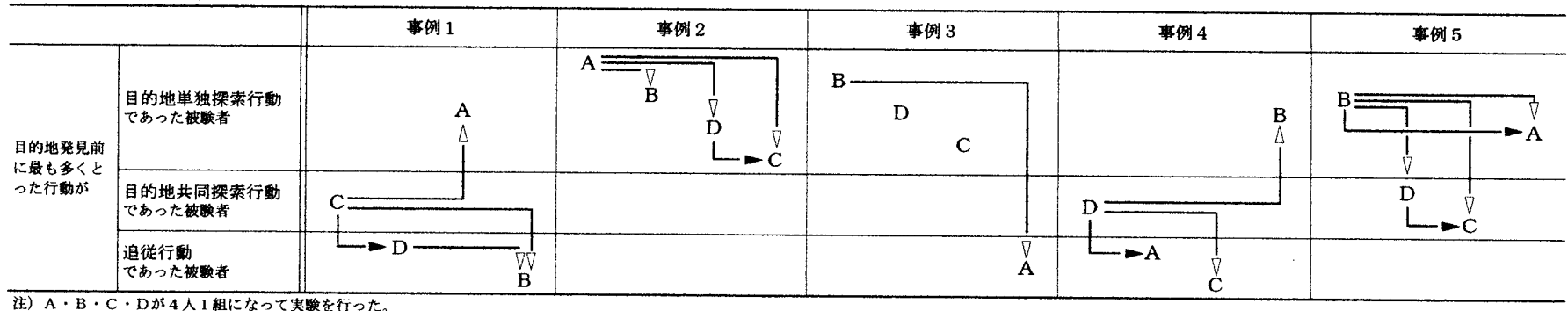

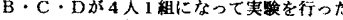

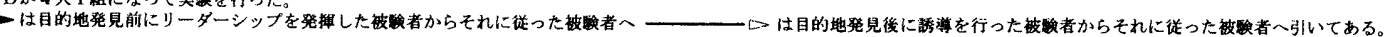


と、独力で探索しようとする Bのペアである。BがAにあまり気を 使わず行動したため、AはBをしばしば見失い単独行動になること もあった。CD組：積極的に追従したがるCと、他者に対してこま めに気遺いするDのペアである。CはDに追従した。DはCの同行 をつねに確かめながら積極的に探索し、リーダーシップを発揮した。 協畔型实䀫 前実験同様追従したがるAは、こまめに気遗いするD に従った。DはAに対しリーダーシップを発揮しながら探索した。 Bは独力で探索しようとした。CはBに追従したり、単独で探索し たり、待機したりさまさまな行動をした。先に目的地を発見したD は、同行していた Aをそこに待機させ、B、Cを探索し、誘導した。

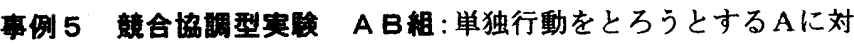
し、Bははじめどうしようか迷うが、別々に探索することを選ぶ。 CD組:積極的に情報交換しながら共同で探索した。経路の選択は、

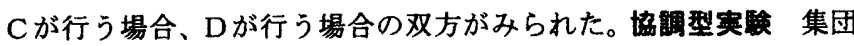
で探索しようとするB、別れて探索しようとするD、態度が不明確 なCが話し合った結果、前実験と同じ 2 組のペアで別れて探索する ことになり、Aもそれに従う。AとBの探索経路の分担はBが決定 し、 $\mathrm{C}$ とDの分担は Dが決定した。先に目的地を発見した Bが、他 の3人を誘導した。実験開始時に待ち合わせの約束をしていたため、 効率的に探索でき、短時間で実験が終了した。

各実䤅中の被験者を目的地発見前に最も多くとった行動によって 分類し、これと集団内でみられたリーダーシップとの関係を調べる （表 7）。目的地発見前に目的地共同探索行動を多くとる者が、リー ダーシップを発揮する傾向が強い。

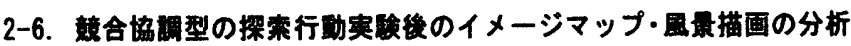

風景が描画できた被験者は、建築を専攻する一部の学生のみだっ たが、大部分の被験者がサインの名前を $1 \sim 9$ 個程度書けた。目的 地共同探索行動を多くとる被蹹者（図 6 中事例 1 被験者 Cなど) は、 あまり経路に迷わなければイメージマップをかなり正確に描け、サ インの場所も多く記入できる傾向がある。目的地共同探索行動を多 くとらなかった被験者の場合、断片的な地図や見たサインの名前を 描けても、これら相互の関連づけができない傾向があった。全く描

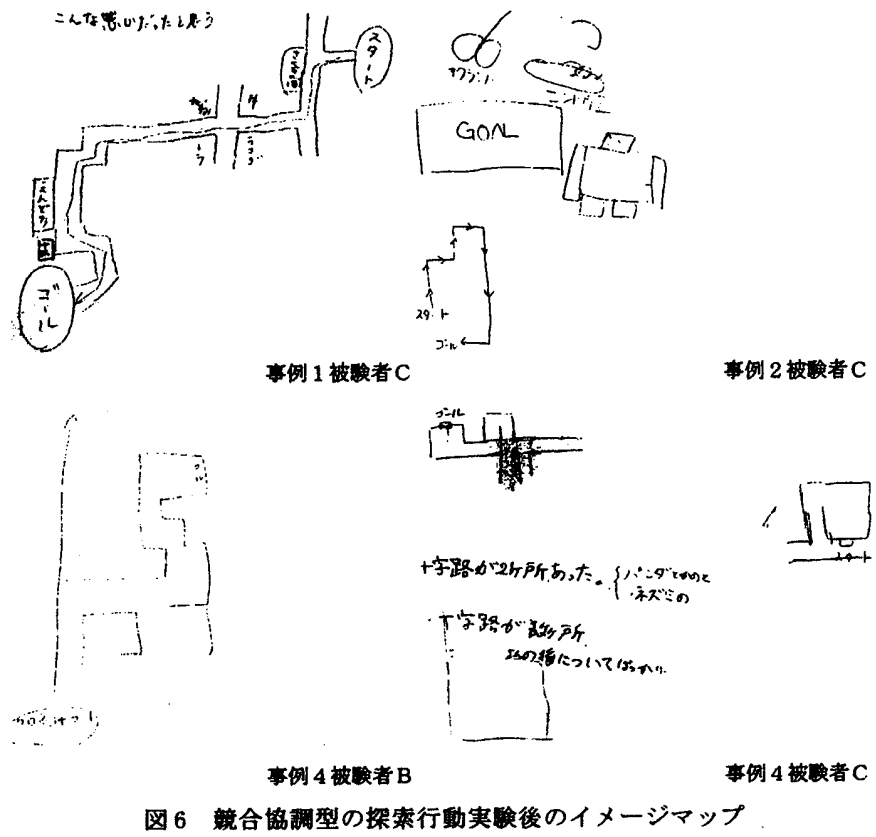

画できない被験者もみられた。

\section{結铻}

本研究では、仮想現実空間内で音声や表情による情報交換が可能 なシステムである Freellalk-VRML を開発した。このシステムを用 いることにより、4人の被験者からなる集団で探索方法や探索経路、 会話の制限を加えずに実験を行い、会話や歩行軌跡のデータを詳細 に記録することが可能になり、以下のことが明らかになった。

1) 目的地発見前は目的地探索、追従行動を、発見後は歩行者探索、 待機、誘導の諸行動を多くとる。競合協調型の探索行動実験では目 的地共同探索行動が多く、協調型の探索行動実験では目的地単独探 索、待機、誘導行動が多い。

2) 目的地発見前では目的地共同探索行動、発見後は誘遵行動を多く とる者が、集団内でより積極的に情報交換を行い、リーダーシップ を発揮する傾向がある。

3）目的地発見前は璄境や情報交換による要因、発見後は他者との位 置関係や内的要因による状態僄移が多い。

4) 目的地共同挆索行動を多くとる者は、イメージマップをより詳細 に描画でき、サインの場所も多く記入できる傾向がある。

\section{謝辞}

実験のシステム開発にあたり協力下さった中田稔君(京都大学大学 院情報学研究科修士課程)に感謝いたします。

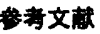

1)岡崎甚幸，昖下湓 : 巨大迷路探索歩行実験における経路イメージおよび歩行 経略のためのシミュレーションモデルの研究，日本建筑学会計画系骿文報告集 No. 441 , pp. $71 \sim 79,1992.11$

2) 北溃享，三浦利章，岡䗁甚幸，筥原一光，田村仁志，松井裕子：迷路探索 歩行時の注視と歩行に関する研究，人間工学 35, No. 3, pp. $145 \sim 155,1999.6$ 3)德永貴士，中村真俉，伊藤明宏，鈴木利友，岡崎甚幸 : 地下鉄駅舍の特徽 的な場面における注視と步行行動一地下鉄駅舎における探索歩行に関寸る研究 その 1-，日本建筮学会学術諈演梗概集 (中国)，E-1，pp. $811 \sim 812 ， 1999.9$ 4) 舟橋國男 : 初期環境情邽の差異と経路探索行動の特徽一不整形街路網地区に おける環境情報の差異と経路探案行動ならびに空間把握に関する研究 その1，日本建筇学会計画系綸文報告集 No. 424, pp. $21 \sim 30,1991.6$ 5) 釘原直榯 : パニック実験 一危機事热の社会心理学一, ナカニシヤ出版, 1995.

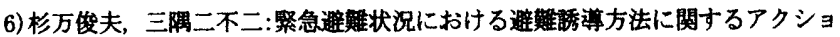

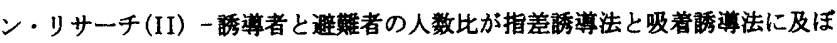
す効果-, 実睮社会心理学研究 Vol. 23, No. 2, pp. 107〜 115, 1984.

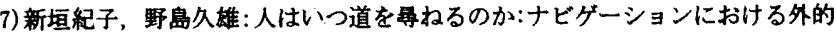
源としての他者，知科学 Vol. 5, No. 3, pp. $49 \sim 58,1998.9$

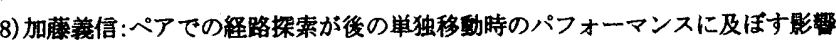
一移動中のコミュニケーションに注目してー, 認知科学 Vol. 5 , No. 3, pp. 36〜 48, 1998.9

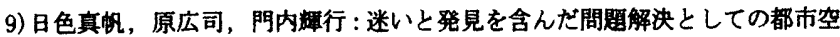
間の経路探索，日本建築学会計画系論文集 No. 466, pp. $65 \sim 74,1994.12$ 10) 中西英之，吉田力，西村俊和，石田亭：FreeValk:3次元仮想空間を用いた 非形式的なコミュニケーションの支援，情報処理学会諭女諾 Vol. 39, No. 5, pp. $1356 \sim 1364,1998.5$

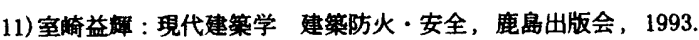

12)Bales, R.F. : Interaction process analysis:a method for the study of small groups, Addison-wesley Press, 1950. 友田不二男, 手塚郁恵訳 : ク ループ研究の方法, 岩绮学街出版社, 1971 . 